\title{
HUBUNGAN ANTARA PEMBERDAYAAN PSIKOLOGIS DAN KOMITMEN KARIER GURU
}

\author{
Dwi Setya Ariani \\ Fakultas Psikologi Universitas Kristen Satya Wacana
}

\begin{abstract}
The purpose of this research is to verify the correlation between Psychological Empowerment and Career Commitment. There are two scales used in this research, i.e. Psychological Empowerment Scales by Spreitzer (1995) and Career Commitment Scale by Carson \& Bedeian (1994). The participants of this research are 60 teachers of private high-school in Salatiga, Indonesia. Data analysis uses SPSS 16 Program. Statistic's method to be used is pearson product moment correlation test. The result of statistic test shows that there is significant correlation between Psychological Empowerment and Career Commitment.
\end{abstract}

Key words: Psychological Empowerment, Career Commitment, teachers at private high-school in Salatiga, Indonesia.

\section{PENDAHULUAN}

Mutu pendidikan merupakan salah satu tolok ukur kemajuan sebuah bangsa. Berbicara mengenai kualitas pendidikan pastilah melibatkan peran 'pendidik', baik guru maupun dosen. Pendidik yang dimaksud adalah pendidik profesional yang berfungsi meningkatkan mutu pendidikan nasional (sumber: Pasal 4 UU RI No.14 tahun 2005 tentang guru dan dosen). Upaya memaksimalkan fungsi guru untuk meningkatan mutu pendidikan bukan hal yang mudah. Hal paling dasar dimulai dari perhatian terhadap SDM guru itu sendiri. Berkaitan dengan SDM guru, Indonesia memiliki prinsip profesionalitas untuk profesi guru yang tertulis pada Pasal 7 UU RI No.14 Tahun 2005 tentang guru dan dosen, yang menegaskan bahwa seorang guru maupun dosen harus memiliki 'komitmen' dalam profesinya.

Sejalan dengan hal tersebut, Weick dan McDaniel (dalam Somech \& Bogler, 2002) menegaskan bahwa pekerjaan sebagai seorang 'guru' mensyaratkan 'komitmen' yang tinggi melebihi hasrat untuk mendapat uang/materi, serta mensyaratkan adopsi nilai-nilai spesifik yang berkaitan dengan pekerjaan tersebut. Hal ini jelas menegaskan bahwa 'komitmen' merupakan salah satu aspek yang dituntut dalam profesi guru.

Secara teoritis, komitmen guru terhadap karier (Komitmen Karier guru) merupakan motivasi guru untuk melakukan segala aktifitas yang selaras dengan nilai-nilai/tuntutan profesi guru (Carson \& Bedeian, 1994). Apa peran/pentingnya 'komitmen' guru terhadap karier ? Mengacu pada pendapat Carson dan Bedeian 
(1994) tersebut, maka guru yang memiliki komitmen terhadap karier diasumsikan berpikir fokus kepada satu profesi (guru) yang saat ini sedang dijalani, serta membuat keputusan untuk berperilaku yang mengarah kepada perkembangan karier dalam profesi tersebut. Hal ini jelas akan membentuk figur guru yang mampu bertahan menghadapi tantangan dan mampu meningkatkan kualitas diri mengikuti tuntutan profesi. Pada akhirnya, guru yang memiliki Komitmen Karier tinggi dimungkinkan mengalami pertumbuhan intelektual dan skill sesuai bidang tugas, sehingga didikan dan ilmu yang diberikan kepada siswa berkualitas dan selalu update.

Selain itu, Komitmen Karier guru patut menjadi perhatian mengingat terdapat dampak negatif yang ditemukan bila seorang guru tidak memiliki Komitmen Karier. Guru yang tidak memiliki Komitmen Karier cenderung berpikir dan berperilaku ganda dalam hal profesi, seperti: berpikir untuk alih profesi, bertindak curang/menghalalkan segala cara untuk m,eraih keuntungan sebesarbesarnya dalam bekerja, serta memiliki daya juang yang rendah saat menghadapi tantangan (Farisi, 2011; Sukadi, 2007).

Berdasarkan peran Komitmen Karier guru serta mengingat dampak negatif bila seorang guru tidak memilikin Komitmen Karier, maka penulis tertarik untuk meneliti Komitmen Karier guru di Salatiga, khususnya pada guru 'SMA swasta binaan Disdikpora' kota Salatiga.

Oleh karena mewujudkan Komitmen Karier guru tidak mudah dilakukan, maka penulis mencoba melakukan identifikasi faktor-faktor yang disinyalir berpengaruh kuat terhadap Komitmen Karier guru. Salah satu faktor yang disinyalir menghambat guru untuk berkomitmen penuh terhadap karier adalah masalah ekonomi, bahwa penghargaan terhadap profesi guru hanya sekadar pujian "Pahlawan Tanpa Tanda Jasa" sedangkan nasib guru terjebak dalam kemiskinan (Sukadi, 2007). Penghasilan yang minim mendesak guru untuk mencari tambahan penghasilan sehingga kurang waktu untuk membaca, menulis, meningkatkan diri, dan pada akhirnya menjalankan profesi secara tidak profesional (Farisi, 2011).

Lebih lanjut, masalah ekonomi sebenarnya telah terjawab dengan adanya program sertifikasi untuk para guru. Namun, kembali lagi masih ditemukan kelemahan dalam program sertifikasi. Fenomena yang ada di sekolah-sekolah adalah guru-guru yang dipanggil untuk sertifikasi hanya mengejar komponen portofolio yang relatif mudah, seperti mengikuti seminar sebagai formalitas untuk mendapat sertifikat (Farisi, 2011). Seperti pernyataan Fasli Jalal dalam workshop Kepala Sekolah SMK se-kota Semarang bahwa sangat sedikit bapak Ibu guru peserta uji sertifikasi yang melampirkan komponen karya pengembangan profesi (Farisi, 2011). Hal ini jelas bertentangan dengan idealnya seorang guru yang memiliki Komitmen Karier. Oleh karena itu, faktor ekonomi bukanlah faktor 
tunggal dan bukan faktor utama yang selama ini diduga menghambat terbentuknya Komitmen Karier guru.

Terdapat faktor-faktor lain yang dapat mempengaruhi Komitmen Karier guru. Faktor internal berasal dari dalam diri guru itu sendiri, yang dapat berupa minat terhadap profesi guru maupun karakteristik personal guru (usia, gender, status pernikahan, dan sebagainya). Sebagai salah satu faktor internal, Pembedayaan Psikologis (Psychological Empowerment) merupakan peningkatan motivasi intrinsik individu terhadap tugas/pekerjaannya (Speritzer, 1995). Guru dengan tingkat Pemberdayaan Psikologis yang tinggi mampu meredam rasa ketidakmampuan dan terhindar dari hilangnya kendali atas dirinya sendiri dalam melakukan pekerjaan sebagai guru (Spreitzer, 2007). Kemampuan meredam rasa ketidakmampuan serta kuatnya kontrol diri tersebut memungkinkan guru untuk bertahan dan berperilaku sejalan dengan tuntutan profesi, dengan kata lain mencapai tingkat Komitmen Karier yang tinggi.

Penjelasan tersebut sejalan dengan hasil penelitian Bogler dan Somech (2004) yang memberi bukti bahwa dari enam diemnsi Pemberdayaan Psikologis, tiga diantaranya (self-efficacy, professional growth, dan status) merupakan prediktor signifikan Komitmen Karier guru. Ketiga dimensi tersebut mampu menjelaskan $40 \%$ dari seluruh varian yang mempengaruhi Komitmen Karier guru.

Bagaimana Pemberdayaan Psikologis berinteraksi dengan Komitmen Karier guru? Pada penelitian Bogler dan Somech (2004), hal tersebut terjadi melalui beberapa proses. Melalui self-efficacy, guru yang memiliki harapan tinggi terhadap diri sendiri untuk sukses di sekolah akan mengeluarkan fungsi-fungsi ekstra dari dalam dirinya. Pada akhirnya guru tersebut merasa lebih berkomitmen terhadap sekolah dan profesinya sebagai guru. Hal ini berdasarkan pada teori Albert Bandura (Bogler \& Somech, 2004) tentang outcome expectancy (individu memperkirakan bahwa suatu perilaku dapat menghasilkan outcome tertentu) dan efficacy expectancy (perilaku ke arah outcome yang diharapkan).

Melalui status, guru yang merasa diperlakukan secara profesional, diakui, dan dihargai kompetensinya oleh kolega guru di sekolah, cenderung lebih berkontribusi terhadap sekolah. Kontribusi tersebut diekspresikan melalui besarnya komitmen terhadap karier dan sekolah (Bogler \& Somech, 2004). Melalui professional growth, guru yang merasa bekerja dalam lingkungan kondusif yang menstimulasi pertumbuhan dan perkembangan profesi akan merasa berkomitmen terhadap kariernya (Bogler \& Somech, 2004).

Berlawanan dengan hasil-hasil penelitian di atas, penelitian Bogler dan Somech (2002) menunjukkan bahwa tidak semua dimensi Pemberdayaan Psikologis bepengaruh terhadap Komitmen Karier guru. Dimensi participation in decision making (partisipasi dalam pengambilan keputusan) ditemukan 'tidak' berpengaruh 
terhadap Komitmen Karier guru. Dengan demikian, masih terdapat pro kontra mengenai pengaruh Pemberdayaan Psikologis terhadap Komitmen Karier.

Serangkaian penjelasan mengenai hasil-hasil penelitian di atas menekankan bahwa masih terdapat pro kontra mengenai keterkaitan antara Pemberdayaan Psikologis dan Komitmen Karier. Berdasarkan hal tersebut, maka penulis melalui penelitian ini mencoba untuk menguji hubungan antara Pemberdayaan Psikologis dan Komitmen Karier pada guru SMA swasta umum binaan Disdikpora kota Salatiga.

\section{METODE PENELITIAN}

Partisipan dalam penelitian ini adalah 60 orang guru yang bekerja di 3 SMA swasta umum binaan Disdikpora kota Salatiga, yaitu: SMA Kristen 1, SMA Kristen 2, dan SMA Kristen Satya Wacana, yang diambil secara acak dari 5 SMA swasta umum binaan Disdikpora kota Salatiga.

Alat ukur dalam penelitian ini terdiri dari 2 skala, yaitu: Skala Komitmen

Karier dan Skala Pemberdayaan Psikologis. Skala Komitmen Karier yang digunakan dalam penelitian ini adalah hasil modifikai dari Career Commitment Scale milik Carson \& Bedeian (1994). Career Commitment Scale tersebut digunakan dalam penelitian Carson dan Bedeian (1994) dan terbukti memiliki properti psikometrik yang dapat diterima dengan koefisien reliabilitas berkisar antara 0.79-0.85. Skala tersebut memiliki tiga subskala sesuai dengan aspek Komitmen Karier, yaitu subskala Career Identity, Career Resilience, dan Career Planning.

Alat ukur Pemberdayaan Psikologis yang digunakan dalam penelitian ini adalah Skala Pemberdayaan Psikologis hasil modifikasi dari Psychological Empowerment Scale milik Spreitzer (1995). Skala Pemberdayaan Psikologis tersebut telah digunakan dalam penelitian Spreitzer (1995) dan memiliki koefisien realibilitas sebesar 0.72. Skala tersebut memiliki empat subskala sesuai dengan aspek Pemberdayaan Psikologis, yaitu subskala Meaning, Competence, Self Determination, dan Impact.

Seleksi aitem dan uji reliabilitas alat ukur dilakukan dengan bantuan program SPSS 16. Seleksi aitem dilakukan dengan menyisihkan aitem dengan nilai corrected item total correlations < 0,25 (Azwar, 1999). Berikut adalah hasil seleksi aitem dan uji reliabilitas alat ukur dengan $N=60$; taraf signifikansi 5\%: 1) Skala Komitmen Karier. Dari 25 aitem, terdapat 4 aitem yang tidak dapat dipertahankan. Terdapat 24 aitem yang dianggap layak dan memiliki koefisien cronbach alpha sebesar 0,86; 2) Skala Pemberdayaan Psikologis. Dari 25 aitem, terdapat 2 aitem yang tidak dapat dipertahankan. Terdapat 23 aitem yang dianggap layak dan memiliki koefisien cronbach alpha sebesar 0,90 . 


\section{HASIL DAN PEMBAHASAN}

Data yang diperoleh dari penelitian ini dianalisa menggunakan metode statistik regresi linier berganda dengan bantuan program SPSS 16.

\section{Hasil Uji Korelasi}

Berdasarkan tabel 1 di bawah, terlihat bahwa nilai- $p$ adalah 0.043 (lebih kecil dari 0.05) maka hasil penelitian ini menolak $\mathrm{H}_{0}$ dan menerima $\mathrm{H}_{1}$ yang berarti bahwa terdapat hubungan yang signifikan Pemberdayaan Psikologis dan Komitmen Karier Pada Guru SMA Swasta Umum Binaan Disdikpora Kota Salatiga. Hubungan yang terjadi antara Pemberdayaan Psikologis dan Komitmen Karier tersebut bersifat positif, dengan koefisien pearson correlation sebesar 0,262. Hal ini berarti bahwa semakin tinggi Pemberdayaan Psikolgis maka semakin tinggi Komitmen Karier. Demikian juga sebaliknya, semakin rendah tingkat Pemberdayaan Psikologis maka semakin rendah Komitmen Karier.

\section{Tabel .1}

Korelasi Pemberdayaan Psikologis dan Komitmen Karier Pada Guru

Correlations

\begin{tabular}{|ll|r|r|}
\hline & & $\begin{array}{c}\text { Pemberday aa } \\
\text { n Psikologis }\end{array}$ & $\begin{array}{c}\text { Komitmen } \\
\text { Karier }\end{array}$ \\
\hline Pemberday aan & Pearson Correlation & 1.000 & $.262^{*}$ \\
Psikologis & Sig. (2-tailed) &. & .043 \\
& $\mathrm{~N}$ & 60 & 60 \\
\hline Komitmen Karier & Pearson Correlation & $.262^{*}$ & 1.000 \\
& Sig. (2-tailed) & .043 &. \\
& $\mathrm{~N}$ & 60 & 60 \\
\hline
\end{tabular}

* Correlation is signif icant at the 0.05 level (2-tailed).

\section{Pembahasan}

Berdasarkan uji korelasi, pada Tabel 3.1 di atas diperoleh nilai- $p 0.043$ (lebih kecil dari 0.05). Oleh karena itu, dapat dikatakan bahwa terdapat hubungan yang signifikan Pemberdayaan Psikologis dan Komitmen Karier.

Terdapat kemungkinan terjadinya interaksi antara Pemberdayaan Psikologis dan Komitmen Karier, yaitu:

Guru yang memiliki pandangan bahwa keyakinan dan penguasaan diri terhadap profesi adalah hal yang penting, kemudian menghayati pandangan tersebut dan merefleksikannnya pada keadaan riil sehingga membentuk identitas diri. Oleh karena keyakinan dan penguasaan diri terhadap seluruh aspek profesi 
(Pemberdayaan Psikologis) menjadi bagian dalam identitas diri guru, maka semakin kuat individual characteristics (Pemberdayaan Psikologis) tesebut semakin besar kemungkinan guru mengambil keputusan dan berperilaku konsisten dengan hakekat profesi serta searah dengan pertumbuhan karier sebagai guru (Komitmen Karier).

Asumsi di atas berlandaskan pada teori career motivation London (1983) mengenai interaksi individual characteristics dan career decision and behavior "Interaksi Individual characteristics dan decisions and bevaiors dapat terjadi dan semakin kuat pengaruhnya jika individual characteristic semakin stabil dan terintegrasi dalam konsep diri (self consept) individu".

\section{SIMPULAN DAN SARAN}

\section{Simpulan}

Penelitian mengenai hubungan antara Pemberdayaan Psikologis dan Komitmen Karier pada guru SMA swasta umum binaan Disdikpora kota Salatiga ini menghasilkan data yang mengindikasikan bahwa terdapat hubungan yang signifikan Pemberdayaan Psikologis dan Komitmen Karier.

\section{Saran}

\section{Saran Bagi Sekolah}

Hasil penelitian menunjukkan bahwa terdapat hubungan yang signifikan Pemberdayaan Psikologis dan Komitmen Karier. Temuan ini diharapkan menjadi pedoman bagi sekolah dalam menyusun kebijakan/peraturan sekolah yang mendorong Pemberdayaan Psikologis guru, seperti: memberikan kelonggaran kepada guru untuk menerapkan ilmu maupun strategi mengajar, mengusahakan para guru untuk melanjutkan pendidikan, membiasakan iklim demokratis atau terbuka terhadap usulan yang muncul dari para guru terkait sistem belajar mengajar. Dengan demikian, diharapkan para guru mampu berkembang mencapai potensi dan prestasi yang maksimal sehingga dimungkinkan bertahan dan berkembang sepanjang kariernya sebagai guru, dengan kata lain mencapai tingkat Komitmen Karier yang tinggi.

\section{Saran Bidang Penelitian}

Berdasarkan pengalaman penulis selama melakukan penelitian ini dengan memperhitungkan berbagai kelemahan dalam penelitian ini, penulis sangat menyarankan bagi peneliti selanjutnya untuk melakukan penelitian melibatkan partisipan guru dari SMA negeri untuk meningkatkan generalisasi hasil penelitian. Hal tersebut juga dimaksudkan supaya diperoleh perbandingan antara guru SMA 
swasta dan guru SMA negeri, sehingga diketahui karakteristik hasil penelitian pada kedua jenis SMA tersebut.

Selain itu penulis juga menyarankan bagi peneliti selanjutnya, jika dimungkinkan, untuk melakukan pengambilan data penelitian serentak dengan mengumpulkan partisipan penelitian. Hal ini dimaksudkan untuk meminimalisir jumlah angket yang cacat (tidak sempurna) maupun mencegah angket yang tidak dikembalikan.

\section{DAFTAR PUSTAKA}

Azwar, S. 1999a. Penyusunan skala psikologi. Yogyakarta: Pustaka Pelajar.

Bogler, R., \& Somech, A. 2004. Influence of teacher empowerment on teachers' organizational commitment, professional commitment and organizational citizenship behavior in school. Teaching and Teacher Education, 20, 277 289.

Carson, K. D., \& Bedeian, A. G. 1994. Career commitment: construction of a measure and examination of its psychometric properties. Journal of Vocational Behavior, 44, 237-262.

Farisi, M. I. 2011. Fakta-fakta penelitian tentang profesi guru dan pengembangan profesi guru. Interaksi: Jurnal Kependidikan, 6 (5), 1-8.

London, M. 1983. Toward a theory of career motivation. Academy of Management Review, 8 (4), 620-630.

Somech, A. \& Bogler, R. 2002. Antecedents and consequences of teacher organizational \& professional commitment. Educational Administration Quarterly, 38 (4), 555-557.

Spreitzer, G. M. 1995. Psychological empowerment in the workplace: dimensions, measurement, and validation. Academy of Management Journal, 38 (5), 1442-1465.

Spreitzer, G. M. 2007. Giving peace a chance: organizational leadership, empowerment, and peace, Journal of Organizational Behavior, 28, 10771095.

Sukadi. 2007. Guru yang profesional dan tunjangan profesi guru. Jurnal Pendidikan dan Pengajaran UNDIKSHA, 523-539.

UU RI No.14 tahun 2005 tentang guru dan dosen. 